\title{
Nieustająca Komisja Obrachunkowa. O kontroli państwowej w Rzeczypospolitej Krakowskiej
}

I. Badacze Rzeczypospolitej Krakowskiej (1815-1846) często wydają się zapominać o tym, że ta oaza polskości w swych liczących ponad 30 lat dziejach miała również działający, choć epizodycznie, organ kontroli państwowej. Sprawę pominął badający historię kontroli państwowej w Polsce Ryszard Szawłowski ${ }^{1}$, nie wspomniał o niej opisujący ustrój i prawo Wolnego Miasta Krakowa Wojciech M. Bartel ${ }^{2}$, a historycy zajmujący się dziejami Rzeczypospolitej Krakowskiej wspominali o niej jedynie w kontekście walki politycznej opozycji z władzami. Dlatego tym bardziej potrzebna wydaje się analiza funkcjonujących na tym terytorium rozwiązań.

Rzeczpospolita Krakowska (Wolne, Niepodległe i Ściśle Neutralne Miasto Kraków i Jego Okręg), licząca niewiele ponad tysiąc kilometrów kwadratowych, znajdowała się - jak wiemy - pod opieką dworów Opiekuńczych (Austrii, Prus i Rosji). Powstała na skutek decyzji zapadłych na kongresie wiedeńskim w 1815 r. Początkowo jej ustrój wyznaczała konstytucja z 1815 r., rozwinięta w 1818 r. Władzę wykonawczą sprawował Senat Rządzący, władzą ustawodawczą było zbierające się corocznie Zgromadzenie Reprezentantów, zwane często po prostu Sejmem lub Izbą. Temu zbierającemu się corocznie organowi parlamentarnemu powierzono uchwalanie budżetów i sprawdzanie rocznych rachunków administracji publicznej. Obie konstytucje jednak nie przewidywały istnienia osobnego organu kontroli państwowej.

Wydany w 1817 r. „Statut tyczący się urządzenia zgromadzeń politycznych" przewidywał, iż gdy tylko zebrany sejm wybierze Komisję Skarbowa, to Senat prześle tejże rachunki z poprzedniego roku finansowego do sprawdzenia. Komisja miała sprawdzać rachunki dochodów i wydatków, aby przedsta-

${ }^{1}$ R. Szawłowski, Najwyższe państwowe organy kontroli w Polsce w XIX wieku. Główna Izba Obrachunkowa Księstwa Warszawskiego oraz Izba Obrachunkowa i Najwyższa Izba Obrachunkowa Królestwa Polskiego, lata 1808-1866, Warszawa 1999.

${ }^{2}$ W.M. Bartel, Ustrój i prawo Wolnego Miasta Krakowa (1815-1846), Kraków 1976. 
wić później Izbie, czy zgadzają się one z budżetem i czy publiczne pieniądze zostały użyte na właściwe cele. Izba z kolei mogła tylko zgłosić Senatowi dostrzeżone nieprawidłowości ${ }^{3}$. Ale nawet takich skromnych możliwości kontrolnych Zgromadzenie sprawować w rzeczywistości nie mogło - szczupłość czasu, na jaki zbierał się ten organ i skomplikowana materia rachunków uniemożliwiały sejmowej Komisji Skarbowej zajęcie się kontrolą ${ }^{4}$. Wielokrotnie bezskutecznie zwracano się do Senatu, aby stworzyć możliwość weryfikacji rachunków poza krótkim okresem obrad Zgromadzenia Reprezentantów ${ }^{5}$.

Wewnątrz samego Senatu istniało Biuro Rachunkowe, które podlegało Sekretarzowi Generalnemu. Zatrudniać miało ono dwóch rachmistrzów i dwóch adiunktów (w późniejszym okresie zostało rozbudowane), a do jego obowiązków należało m.in. sprawdzanie poprawności wszelkich rachunków, które miał później zatwierdzać Senat. Chodziło nie tylko o weryfikację poprawności rachunkowej, ale również o to, by rachunki te „monitować, zgłębiać”, w celu umożliwienia późniejszego przedstawiania do nich uwag. Biuro służyć miało pomocą senatorom, przy kontrolowaniu kas ${ }^{6}$. Działania Biura miały oczywiście charakter kontroli innych jednostek państwowych, czy to Kasy Głównej czy choćby kasy ekonomii czernichowskiej ${ }^{7}$.

II. Powstanie kontroli państwowej w Rzeczpospolitej Krakowskiej wiąże się z ograniczeniem samodzielności tego swoistego państewka, ukształtowanego na skutek interwencji mocarstw opiekuńczych. Kryzys polityczny, zapoczątkowany wybraniem w 1827 r. na nowego prezesa Senatu Józefa Nikorowicza, w miejsce sprawującego ten urząd od początków Wolnego Miasta hrabiego Stanisława Wodzickiego, zaowocowało głęboką ingerencją trzech dworów i znacznymi zmianami polityczno-prawnymi. Przywrócono na stanowisko Wodzickiego, anulowano ważność ostatniego Zgromadzenie Reprezentantów, a w kolejnych latach organ ten przestał być zwoływany.

Reformy ustrojowe ostatecznie przeprowadziła Komisja Reorganizacyjna, złożona z przedstawicieli Austrii, Prus i Rosji. Zmiany znalazły formalne ujście w nowej Konstytucji z 1833 r. Uformowana została stała Konferencja Re-

${ }^{3}$ Statut tyczqcy się urzqdzenia zgromadzeń politycznych, art. 132-135, [w:] Dziennik Rozporzadzeń Rzadowych Wolnego, Niepodległego i ściśle Neutralnego Miasta Krakowa i Jego Okręu [cyt. dalej: DRR] r. 1817.

${ }^{4}$ „Stosami akt i dowodów założonemi były salony Prezydującego w Komisji Skarbowej”, a Senat robił to „w przekonaniu, że ich nikt sprawdzać nie będzie, bo na to nie było czasu” (Hilary Meciszewski); „ich weryfikacją nie mogła nigdy zająć się Komisja”, gdyż „nieprzełamanych zawsze z strony Senatu doznawała przeszkód" (Kajetan Florkiewicz), Dyaryusz Seymu Wolnego, Niepodległego i Ściśle Neutralnego Miasta Krakowa i Jego Okręgu za rok 1837/8 [cyt. dalej: Diariusz Sejmu 1837/38], s. 80, 82.

${ }^{5}$ Diariusz Sejmu 1837/38, s. 83.

${ }^{6}$ Urzadzenie Wewnętrzne Senatu Wolnego Miasta Krakowa i Jego Okregu, [w:] DRR, r. 1816.

${ }^{7}$ Archiwum Państwowe w Krakowie [cyt. dalej: APK], WMK VII 1, k. 583-584, 623-624. 
zydentów, czyli organ złożony z przedstawicieli trzech mocarstw, który miał czuwać nad przestrzeganiem Konstytucji oraz pełnić rolę arbitra w konfliktach między Senatem a Zgromadzeniem Reprezentantów. Samo Zgromadzenie miało być odtąd zwoływane jedynie co trzy lata, na taki sam okres miał być uchwalany budżet. Co jednak istotne, ze względu na tak niską częstotliwość zbierania się Sejmu, miał on wybierać ze swego grona, dla sprawowania kontroli, Nieustającą Komisję Obrachunkową (NKO). Ciało to miało kontrolować i porządkować rachunkowość, „stosownie do prawideł postanowionych”. Komisji przyznano też prawo do wnoszenia i oskarżania przed Sąd Najwyższy, z inicjatywy Senatu lub własnego członka, każdego senatora i urzędnika publicznego, ,który by stał się winnym zgwałcenia Konstytucji, lub został obwiniony o kradzież publicznego grosza, o zdzierstwo albo nadużycie władzy"8.

Przepisy konstytucyjne były dość ogólne i zakładały konieczność ich uzupełnienia. Powołano organ o dość szerokich kompetencjach - nie tylko kontroli rachunkowej, ale też posiadający uprawnienia w stosunku do urzędników. Wyróżniało to te rozwiązania na tle innych funkcjonujących na ziemiach polskich - czy współczesnych im, istniejących w Królestwie Polskim, czy wcześniejszych, z epoki Księstwa Warszawskiego. Węższe kompetencje miała Główna Izba Obrachunkowa Księstwa Warszawskiego, czy później Najwyższa Izba Obrachunkowa Królestwa Polskiego. Przede wszystkim nie składały one relacji organom parlamentarnym. NKO bardziej przypominała kształtem francuski Court des Comptes. Ta francuska Izba Obrachunkowa, powołana w 1807 r., posiadająca charakter quasi-sądowy, po rewolucji lipcowej przekształcona została $\mathrm{w}$,organ informacyjny parlamen-

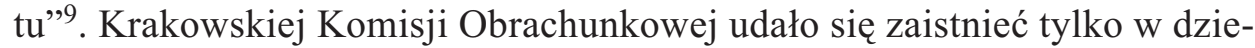
dzinie kontroli państwowej.

Zgromadzenie Reprezentantów, które zebrało się w 1833 r., po raz pierwszy po kilkuletniej przerwie, otrzymało od Senatu Rządzącego drukowany „Ogólny rachunek przychodów i rozchodów”, który obejmował okres od powstania Rzeczpospolitej Krakowskiej do roku budżetowego 1831/32. Dokument ten trafił do Komisji Skarbowej, jednak był to tylko bardzo ogólny szkic, przedstawiający dochody i wydatki w poszczególnych latach ${ }^{10}$. Sugerowano też, aby NKO - w drodze wyjątku - zajęła się rachunkami publicznymi obejmującymi okres od ostatniego sejmu, czego nie była w stanie zrobić zajmująca się tym do tej pory sejmowa Komisja Skarbowa ${ }^{11}$. Bezsprzecznie Komisja Obrachunkowa zająć się miała dopiero rachunkami z roku 1832/33, jako

${ }^{8}$ Art. XIV Konstytucji. Treść przepisów konstytucyjnych cyt. za: A. Tarnowska, Polskie dokumenty konstytucyjne 1790-1848, München 2008.

${ }^{9}$ R. Szawłowski, op. cit., s. 214.

${ }^{10}$ Dyaryusz Seymu Wolnego Niepodległego i Ściśle Neutralnego Miasta Krakowa i Jego Okręgu. Roku 1833 [cyt. dalej: Diariusz Sejmu 1833], s. 25; APK WMK II 45.

${ }^{11}$ Diariusz Sejmu 1833, s. 138-139. 
że zebranemu wkrótce po zakończeniu tego roku finansowego Zgromadzeniu, nie zostały one przedstawione.

Zgodnie z przepisami wskazującymi, że członkami NKO mogą być tylko reprezentanci, którzy na swe funkcje zostali wybrani przez zgromadzenia obiorcze $^{12}$, Zgromadzenie wybrało (na sesji odbywającej się 17 września) ze swego grona trzech członków owej Komisji, oraz dwóch zastępców. Najwięcej głosów uzyskał Kajetan Florkiewicz (co przy braku właściwych przepisów oznaczało objęcie przez niego prezesury ${ }^{13}$ ). Kolejnymi członkami zostali Jan Kanty Piechocki i Franciszek Lipczyński. Zastępcami członków zostali Hilary Meciszewski i Leon Rudowski ${ }^{14}$.

Wybór nie okazał się fortunny, a prezes uchylał się od podjęcia pracy przez ponad dwa lata. Kolejny z członków, Jan Kanty Piechocki, znalazł się w stanie upadłości handlowej, co w świetle ówczesnych przepisów wiązało się z utratą przezeń praw politycznych i uniemożliwiało zasiadanie w Komisji. Nalegali na podjęcie działań pozostali wybrani członkowie. Senat trzykrotnie wzywał Florkiewicza do podjęcia funkcji, aż wreszcie 30 listopada 1835 r. Komisja zebrała się po raz pierwszy. Zrobiła to na wniosek Franciszka Lipczyńskiego; na miejsce dwóch nieobecnych członków weszli zastępcy ${ }^{15}$. Skład Komisji był więc następujący: Franciszek Lipczyński (przewodniczący), Hilary Meciszewski (,pióro trzymający”, tj. sekretarz) i Leon Rudowski.

Być może postępowanie Florkiewicza, który przez długi okres uniemożliwiał powstanie Komisji, było celowe i uzgodnione z Senatem. Był on bowiem i uchodził za członka stronnictwa związanego $\mathrm{z}$ władzami rządowymi, a zwłaszcza z Wodzickim (wówczas już ex-prezesem Senatu), więc zupełnie niezainteresowanego przeprowadzeniem kontroli ${ }^{16}$. Tym bardziej że do Komi-

${ }^{12}$ Statut organiczny o zgromadzeniach politycznych Wolnego Niepodległego i Ściśle Neutralnego Miasta Krakowa i Jego Okręgu, art. 138, Dziennik Praw r. 1833; Zgromadzenie Reprezentantów składało się z kilku kategorii reprezentantów: delegowanych przez Senat, przez Uniwersytet, przez Kapitułę, a także wybranych sędziów pokoju oraz wybranych przez uprawnionych obywateli na zgromadzeniach obiorczych.

${ }^{13}$ APK WM 19, k. 1142.

${ }^{14}$ Diariusz Sejmu 1833, s. 177.

${ }^{15}$ APK WM 19, k. 55.

${ }^{16}$ Sprawa ta nie do końca jest jasna. Pisząca o dziejach rodziny Florkiewiczów J. Dziewulska uważa, niestety nie powołując się na żadne źródła, iż Kajetan Florkiewicz nie przejawiał już zainteresowania działalnością publiczna, stary i schorowany sam opuścił Komisję, a w 1835 r. całkowicie wycofał się z życia publicznego, J. Brzózka, Dzieje rodziny Florkiewiczów herbu Ozdoba z Młoszowej w XIX wieku, Kraków 2006, s. 48, 63. Trudno jednak się z tym zgodzić, gdyż tenże Florkiewicz stanął do wyborów do Zgromadzenia Reprezentantów w 1837 r., w którym następnie zasiadł, obejmując nawet przewodnictwo Komisji Kwalifikacyjnej. Wówczas również słuchał i brał udział w dyskusji o działaniach Komisji Obrachunkowej, której pracę wcześniej sparaliżował. Usprawiedliwił się wtedy, thumacząc, że w roku 1833 został wybrany zarówno do Zgromadzenia, jak i do Komisji Obrachunkowej, podczas swej nieobecności, gdy przebywał u wód, natomiast później nie mógł podjąć pracy ze względu na chore oczy, APK WMK II 41, k. 440. Niemniej, podczas obrad wypowiadał się w duchu opozycyjnym wobec swojego dotychczasowego obozu, zob. Diariusz Sejmu 1837/38, s. 82. 
sji dostał się Meciszewski, znany opozycjonista, który żywo interesował się sprawami finansowymi Wolnego Miasta i ostro występował wobec Senatu na Sejmie 1833 r. Z kolei Lipczyński i Rudowski byli członkami Komisji Skarbowej Sejmu, więc musieli orientować się w problematyce finansowej. W kolejnych latach Lipczyński i Meciszewski mieli odegrać poważną rolę na małej scenie politycznej Wolnego Miasta. Mniej widoczny był Rudowski, który jako były żołnierz nieskutecznie starał się o stanowisko Komendanta Milicji ${ }^{17}$.

Brak było szczegółowych przepisów dotyczących organizacji i sposobu podjęcia działania przez NKO. Poza jednym artykułem Konstytucji i jednym Statutu Organicznego o Zgromadzeniach Politycznych brak było innych regulacji. Z istniejących można było tylko wyczytać skład Komisji i sposób jego powołania, moment zebrania (,w końcu każdego roku etatowego") i cel istnienia (,dla uporządkowania rachunków i przygotowania ich do rewizji przyszłego Sejmu") ${ }^{18}$.

III. Komisja musiała zwalczyć trudności organizacyjne, nim mogła zająć się przepisaną sobie działalnością. Choć Izba chciała, by Komisja zajęła się sprawdzaniem rachunków od powstania kraju, które w rzeczywistości nie były nigdy sprawdzane, jednak było to niemożliwe ze względu na brak czasu i stan tych rachunków ${ }^{19}$.

Trudne było samo rozpoczęcie działalności. Od powołania Komisji minęły dwa lata, a Lipczyński przypominał Senatowi o konieczności podjęcia pracy ${ }^{20}$. Pierwsze zebranie Komisji odbyło się dopiero 30 listopada 1835 r. w kamienicy przy ul. Św. Anny 4, na wniosek jednego z wybranych członków Komisji Franciszka Lipczyńskiego. Komisja postanowiła sama się „zawiązać”, opierając się na istniejących przepisach. Przewodniczącym został Lipczyński, powzięto także decyzję, aby poinformować Senat o swoim powstaniu, podać przyczynę zwłoki, a samemu Florkiewiczowi, który nie podjął się przewodniczenia, zostawić usprawiedliwienie wobec Zgromadzenia Reprezentantów swego postępowania ${ }^{21}$.

Pierwszym problemem Komisji było zdobycie zaplecza organizacyjnego, gdyż - pomimo dwuletniego okresu od momentu stworzenia przepisów ja powołujących - nic nie zostało przygotowane. Jako instytucja działająca w sposób ciągły potrzebowała odpowiednich pomieszczeń do pracy. Proponowane początkowo przez Senat siedziby nie zadowalały członków Komisji, gdyż zamiast w miejscu ,przyzwoitym (...) i dostojności odpowiednim” oferowano pomieszczenia „ciemne i zimne”, a w dodatku oddalone od archiwów, do

\footnotetext{
${ }^{17}$ APK WMK IV 25, k. 138, 142.

${ }^{18}$ Statut organiczny o zgromadzeniach politycznych ..., op. cit.

${ }^{19}$ Diariusz Sejmu 1837/38, s. 90.

${ }^{20}$ APK WMK III 55, k. 541.

${ }^{21}$ APK WM 19, k. 55-56.
} 
których dostęp był istotny przy sprawowaniu kontroli. Dlatego pierwsze posiedzenie NKO poświęcono ułożeniu prośby do Senatu o wyznaczenie dla siebie pomieszczeń w gmachu rządowym. Zażądano również „utensyliów” do pracy, według wykazu. Komisja poleciła też Senatowi zawiadomienie wszelkich władz i jednostek Wolnego Miasta o swoim powstaniu i wydanie im polecenia, aby udzielały objaśnień i udostępniały akta. Komisja zawiadomiła też Senat, iż delegowany do niej dla udzielania wyjaśnień urzędnik Biura Rachuby nie będzie w stanie spełniać swego zadania, albowiem Komisja domagać się będzie urzędowych odpowiedzi na piśmie, gdyż tylko takie mogła wykorzystać przy składaniu przyszłego raportu Zgromadzeniu Reprezentantów. Natomiast sama NKO, aby móc osiagnnąc ciagłość pracy, zatrudniła jednego kancelistę (urzędnika), który prowadzić miał biuro Komisji. Pracownik ten miał otrzymać wynagrodzenie z funduszy budżetowych nadzwyczajnych (,ekstraordynaryjnych”), którymi dysponował Senat. Komisja zgłosiła Senatowi potrzebę zatrudnienia dla swych potrzeb woźnego ${ }^{22}$.

Komisja Obrachunkowa pragnęła jak najszybciej przekształcić się w rzeczywiście działający urząd. Jednak na siedzibę przy ul. Grodzkiej proponowano jej nie dawne kolegium jezuickie, gdzie urzędował Senat, a pobliskie pomieszczenia po Akademii Malarskiej (która na skutek przekształceń w krakowskim szkolnictwie została połączona w 1833 r. z Instytutem Technicznym i opuściła w 1835 r. zajmowane pomieszczenia w Collegium Iuridicum ${ }^{23}$ ). Komisja postanowiła więc żądać wynajęcia innego lokum przy ul. Grodzkiej, lecz ostatecznie usadowiła się przy ul. Wiślnej, gdzie odbyło się jej trzecie posiedzenie $^{24}$. NKO zawarła kontrakt roczny w wysokości 234 zł na najem pomieszczeń, który został zatwierdzony przez Senat wraz z poleceniem opłacania czynszu przez Kasę Główną, począwszy od 15 grudnia 1835 r. ${ }^{25}$

Już na drugim posiedzenia Komisja stanęła przed problemem sposobu wykonywania kontroli. Najpierw postanowiono zwrócić się do Senatu o zaopatrzenie w niezbędne obowiązujące akty prawne, zwłaszcza odnoszące się do finansów i rachunkowości. Jednak problem stanowiły braki w uregulowaniach - nie była ustalona nawet procedura, w jakiej Komisja ma zdawać swój raport sejmowi. Było to tym bardziej istotne, iż Komisja wywodziła się i składała z członków Izby Reprezentantów, a przecież nie było wiadome, czy którykolwiek z nich będzie wybrany na kolejne Zgromadzenie. Dlatego za pośrednictwem Senatu chciano prosić Konferencję Rezydentów, która na wniosek Senatu lub Izby Reprezentantów, zgodnie z art. 27 Konstytucji Wolnego Miasta z 1833 r., zajmowała się jej wykładnią, o wskazanie właściwego sposobu

${ }^{22}$ APK WM 19, k. 56-58.

${ }^{23}$ Zob. L. Ręgorowicz, Dzieje krakowskiej Akademii Sztuk Pięknych, Lwów 1928, passim.

${ }^{24} \mathrm{~W}$ protokole brak daty, ale musiało ono odbyć się pomiędzy 15 (czytano reskrypty oznaczone tą datą) a 21 grudnia (czwarte posiedzenie) 1835 r., APK WM 19, k. 61-62.

${ }^{25}$ APK WMK IV 24. 
działania. Konferencja miała również wyjaśnić sposób, w jaki miała nastąić kontrola ${ }^{26}$. Sprawa ta jednak nie została rozwiązana, Senat ostatecznie odmówił zwrócenia się do Rezydentów, oświadczając, że sprawa znajdzie rozwiązanie, gdy Komisja zwróci się z pytaniem do Zgromadzenia Reprezentantów ${ }^{27}$.

Senat nie tylko w tym aspekcie nie ułatwiał pracy Komisji. Choć zgodził się na realizację i sfinansowanie jej podstawowych potrzeb (lokal, zatrudnienie pracowników, materiały biurowe), to jednak w istotnych kwestiach dotyczących kontroli nie aprobował jej propozycji. Nie zezwolił na bezpośrednie zwracanie się Komisji do poszczególnych instytucji i urzędów po wyjaśnienia - wszystkie wątpliwości należało kierować tylko do Senatu, który miał zajmować się ich wyjaśnianiem ${ }^{28}$.

Komisja otrzymała od Senatu rachunki dochodów i wydatków państwa za rok 1833/34 (rok finansowy trwał od 1 czerwca do końca maja roku następnego). Natomiast Komisja nie była pewna zakresu czasowego przeprowadzanej kontroli, gdyż jej członkowie mieli świadomość, iż Zgromadzenie Reprezentantów wnosiło o sprawdzenie rachunków wyjątkowo nie tylko za okres między sejmami, ale od 1827 r., bo podczas ostatniego Sejmu w 1833 r. takiej kontroli za lata 1827-1833 nie przeprowadzono ${ }^{29}$. W końcu zdecydowano, gdy Senat dał NKO swobodę co do decyzji o weryfikacji tych rachunków, zawiesić taką kontrolę i skupić się na badaniu rachunków bieżących.

Komisja wezwała Senat do przedstawienia rachunków z lat dawnych w sposób zrozumiały, bez przepisywanych w kolejnych latach zaległości. Ale przede wszystkim zwróciła się o przesłanie rozliczeń z roku 1832/33, co też Senat dopełni1 ${ }^{30}$ i tym samym otrzymano materiały niezbędne do rozpoczęcia właściwej pracy.

Nawet jednak w tym momencie nie było jeszcze dane rozpocząc kontrolowania rachunków. Komisja zasypywała Senat różnymi prośbami, choćby przypominając, że jej zadaniem było zbadanie wszystkich funduszów publicznych, nie tylko tych objętych budżetem - stąd konieczność uzupełnienia przez Senat przesłanych sprawozdań oraz podania rzeczywistego stanu kas państwowych $^{31}$. Gdy jednak NKO nie otrzymywała od Senatu odpowiedzi, członkowie Komisji uznali, że nie mogą rozpocząć pracy i zawiesili działalność na niemal dwa miesiące.

Dopiero 16 maja 1836 r. wznowiono prace. Senat poinformował, że na prośbę Komisji wydelegował do pomocy w kontroli dwóch swoich rachmistrzów, którzy mieli jej podlegać i otrzymać za spełniane zadania osobne wy-

\footnotetext{
${ }^{26}$ APK WM 19, k. 59-61.

${ }^{27}$ APK WM 19, k. 67.

${ }^{28}$ APK WM 19, k. 62.

${ }^{29}$ APK WM 19, k. 63; Diariusz Sejmu 1833, s. 138-139.

${ }^{30}$ APK WM 19, k. 64-65.

${ }^{31}$ APK WM 19, k. 65-66.
} 
nagrodzenie. Następnego dnia wspomniani rachmistrze pojawili się w siedzibie Nieustającej Komisji Obrachunkowej, gdzie otrzymali zadanie oddzielenia rachunków zaległych od bieżących i stworzenie „operatu” rachunkowego. Pracę mieli podjąć „,bezprzestannie”, aby jak najprędzej została ukończona. Obiecano im także wynagrodzenie, uzależnione od uznania Komisji i szybkości wykonywania pracy. Natomiast Senatowi oznajmiono, że tylko wyjątkowo Komisja zajmie się oddzieleniem rachunków zaległych od bieżących, i w przyszłości tylko już posegregowane będzie przyjmować ${ }^{32}$. Komisja Obrachunkowa korzystała z usług fachowej pomocy rachmistrzów rządowych, choć też nie odbyło się to bez problemów. Na początku 1837 r. zwolniono rachmistrza Manna, który nie pojawiał się ani w NKO, do której był delegowany, ani w Biurze Rachuby, w którym pracowa ${ }^{33}$.

Senat Rządzący ostatecznie przysłał uporządkowane wedle woli NKO rachunki, więc członkowie Komisji mogli zająć się sprawdzeniem rachunków z roku budżetowego 1832/33. Podzielili oni między siebie zadania kontrolne, według pozycji zawartych w budżecie, rozpoczynając od przychodów. Po tym jednak Komisja dostrzegła, że przedstawione rachunki nie są zatwierdzone przez Senat, zwrócono się więc pilnie o sankcję Senatu dla nich. Było to konieczne, gdyż rewizji poddać należało oficjalnie zatwierdzane rachunki, które miały potem zostać złożone Zgromadzeniu Reprezentantów. Senat ostatecznie potwierdził przesłane rachunki, choć kilkumiesięczny okres przerwy w zebraniach NKO może świadczyć, że nie nastąpiło to od razu. Dopiero 24 października 1836 r. zadecydowano, iż kancelaria sporządzi kopie rachunków, które trafią do członków Komisji, aby ci przedstawiać mieli na nich swe uwagi. Następnie Komisja miała je rozważać i podejmować co do nich decyzję. Regularność i sprawność działania zapewnić miało postanowienie o odbywaniu sesji w każdy poniedziałek i piątek, co nie przekreślało możliwości zebrań nadzwyczajnych $^{34}$.

Jaki status posiadała powołana Nieustająca Komisja Obrachunkowa? Choć często nazywana była Komisją Sejmowo-Obrachunkowa, to miało to uzasadnienie tylko, jeśli chodzi o sposób powołania czy skład, gdyż z innymi komisjami sejmowymi, które działały w czasie trwania obrad Zgromadzenia Reprezentantów, nie miała nic wspólnego. W okresie swej działalności zbierała się na wezwanie swego przewodniczącego bądź na wskazane wcześniej, odroczone posiedzenia.

IV. Brak całości protokołów posiedzeń Komisji uniemożliwia odtworzenie szczegółów jej pracy nad sprawdzaniem rachunków państwowych oraz nad in-

\footnotetext{
${ }^{32}$ APK WM 19, k. 69-71.

${ }^{33}$ APK WMK IV 26, k. 57.

${ }^{34}$ APK WM 19, k. 72-73.
} 
nymi kwestiami. Komisja bowiem oprócz sprawowanej kontroli, przygotowała również projekt statutu, który rozwiać miał dotychczasowe wattpliwości dotyczące sposobu jej funkcjonowania. Miał uregulować stanowisko Komisji, tryb jej działania i kompetencje.

Ten liczący 110 artykułów dokument stanowi niewątpliwie dzieło liberalnych i konstytucyjnych przekonań jego autorów. Już artykuł pierwszy mówił, iż Komisja ,jest Władzą Kraju Konstytucyjną, i w urzędowaniu swoim od żadnej innej Władzy niezależna. Z czynności swoich i prawem określonego obrębu działania zdaje sprawę Izbie Reprezentantów, na najbliższym jej obiorowi zgromadzeniu się Władzy Prawodawczej, i tej tylko a nie innej władzy, usprawiedliwiać się powinna z powierzonej misji”. Projekt przewidywał rozwiązanie istniejących dotąd trudności, w tym sposób zdawania relacji Zgromadzeniu Reprezentantów. Przygotowane sprawozdanie miało podlegać upublicznieniu. W przypadku potwierdzenia przez sejm nieprawidłowości, Senat miał mieć przyznane prawo do wyegzekwowania brakujących przychodów lub żądania zwrotu nieprawidłowych wydatków. Do tego Komisja miała mieć prawo żądania w sprawach weryfikacji rachunków od wszelkich władz wyjaśnień i dokumentów. Określono kompetencje Prezydującego (Przewodniczącego) NKO, jak i niezbędne kompetencje oraz zakres obowiązków pracowników zatrudnionych w biurze Komisji (zarówno stałych, jak i tymczasowych). Ustalono szczegółowe formy rachunków, które Komisja otrzymywać miała od Senatu w terminie trzech miesięcy od końca roku finansowego. Na „monita” skierowane przez NKO Senat miał obowiązek odpowiedzieć w terminie dwóch miesięcy.

Projekt bardzo szeroko określał kompetencje Komisji. W hierarchii władz krajowych miała mieć ona miejsce zaraz za Senatem Rządzącym. Rozwiązania takie jak konieczność, po przedstawieniu sprawozdania NKO, uzyskiwania przez Senat absolutorium w Zgromadzeniu Reprezentantów z wykonania budżetu, stanowiły o projektowanym nowoczesnym, konstytucyjnym kształcie i kompetencjach kontrolnych Nieustającej Komisji Obrachunkowej. Kompleksowość przygotowanego projektu podkreśla opracowanie wraz z nim wzorów formularzy i przepisów przejściowych ${ }^{35}$.

Przygotowany projekt był tylko dodatkiem do sprawozdania $\mathrm{z}$ pracy. Zgodnie z przepisami Konstytucji Komisja zweryfikowała dostarczone przez Senat rachunki, w obszernych materiałach odsłaniając nieznane do tej pory sekrety gospodarki finansowej rządu Rzeczpospolitej Krakowskiej. Według budżetu, wydatki powinny w roku 1832/33 wynieść 1535556 zł, a jak informował Senat, wypłacono 1583683 zł (przy czym przekroczenia były na 155433 zł, a 108306 zł niewykonania). Komisja obliczyła jednak, że wydatki wyniosły w rzeczywistości 1620865 zł, przy czym o 251764 zł przekroczono zapisy bu-

\footnotetext{
${ }^{35}$ APK WMK II 42, k. 1111-1138.
} 
dżetu, a wśród pozycji zapisanych nie wypłacono 167455 zł. Komisja wyliczyła też, iż 105341 zł wydano na cele w budżecie nieprzewidziane, a które mimo to zostały umieszczone w rachunkach. Odkryto także, że 49396 zł wydano na pozycje nieumieszczone $\mathrm{w}$ budżecie, i na które nie przedstawiono nawet rachunków ${ }^{36}$.

Wyniki pierwszej kontroli ukazywały dużą dowolność i odstępstwa Senatu od zapisów budżetu, który przecież stanowił upoważnienie do prowadzenia gospodarki finansowej państwa. Komisja prace swe zakończyła w maju 1837 r. (niemal cztery lata od ostatniego Zgromadzenia Reprezentantów i momentu swego wyboru), wysyłając swe opracowanie wraz z licznymi pytaniami do Senatu. Nie otrzymała jednak na nie odpowiedzi ${ }^{37}$. W tym momencie jej rola uległa zawieszeniu, gdyż nie wiadomo było, kiedy zbierze się Zgromadzenie Reprezentantów. Jeszcze na początku października Senat nakazał opłacenie kosztów najmu biura NKO, zastrzegając, że dalszy najem i wydatki na ten cel zależeć będą od decyzji Konferencji Rezydentów zwołującej sejm ${ }^{38}$. Sejm został jednak zwołany na 28 grudnia 1837 r., i wtedy - przed jego zebraniem Komisja próbowała jeszcze wymusić odpowiedź na swe pisma, starając się wydelegować Meciszewskiego do Senatu. Na nic się to jednak nie zdało, Senat uchylił się od tego, zasłaniając brakiem czasu i thumacząc, że sprawę załatwi nowe, ogólne „urządzenie” rachunkowości ${ }^{39}$.

Wraz z raportem z przeprowadzonej kontroli NKO przekazała Zgromadzeniu Reprezentantów, w przeddzień jego zebrania, wspomniany projekt urządzenia swej organizacji (złożywszy go wcześniej też Senatowi) ${ }^{40}$. Było to nie tylko spełnieniem obowiązku, ale zabezpieczało wyniki kontroli, gdyby (przy niewyjaśnionych sporach i kontrowersjach) wraz z zebraniem sejmu Komisja musiała przestać pracować.

V. Działalność Komisji uwieńczona została podczas obrad Sejmu Rzeczypospolitej Krakowskiej, który zebrał się na przełomie 1837 i 1838 roku. Sprawy Komisji i efektu jej prac, które przewijały się przez całe obrady, należy widzieć na tle szerokiego konfliktu między władzami Wolnego Miasta a opozycją, w której prym wiódł członek Komisji Meciszewski. Wprawdzie wyniki kontroli dotyczyły działalności dawnego składu Senatu (w 1833 r. Komisja Reorganizacyjna wymieniła nie tylko Prezesa, ale i jego członków), jednak ster władzy pozostawał wciąż w rękach tych samych środowisk. Zresztą, w $1833 \mathrm{r}$. wówczas świeżo mianowany nowy prezes Senatu Kasper Wielogłowski, zgłaszał konieczność oddzielenia rachunków z epoki poprzedniego składu rządu od nowych, aby uwolnić się od możliwej odpowiedzialności za przekroczenia zapisów budżetu ${ }^{41}$.

Jeszcze na posiedzeniu sejmowym, nim Komisja złożyła raport ze swych działań, Meciszewski wypominał, że „stawione są przeszkody, by ich dopełnić nie mogła", a Senat liczył, że z rachunkami Komisja Obrachunkowa postępo- 
wać będzie tak jak dotychczas kontrolowała je sejmowa Komisja Skarbowa ${ }^{42}$. Jednak najistotniejsze dla działalności NKO było rozstrzygnięcie znaczenia słowa „nieustająca”. Opozycja uważała, że należy przez to rozumieć działanie do czasu wyboru nowej Komisji przez Sejm, natomiast Senat uważał, że określenie „nieustająca” odnosi się do okresu międzysejmowego, i wraz z pierwszym posiedzeniem tego organu NKO kończy swą pracę ${ }^{43}$. Opierał się przy tym na przepisach, każących Komisji „monita” przekazywać Senatowi, który by wnosił je na Zgromadzenie ${ }^{44}$. To dało pole do ataków na Senat Meciszewskiemu, który oskarżał Senat o niechęć „dla tej nowej rękojmi dobra publicznego" $" 45$.

W uchwalonym przez Sejm memoriale do Konferencji Rezydentów znalazło się sformułowanie, iż ,z natury kontroli wypływa, że kontrolujący nie może zdawać sprawy z zadania swego przed kontrolowanym, ani skutków tak dopełnionej kontroli czynić zawisłym od dobrej lub złej woli kontrolowanego"46. W opinii Senatu, Komisja miała przedstawiać jemu swój raport, aby sam Senat go wnosił do Sejmu, opatrzony w wyjaśnienia ${ }^{47}$. Jednak racjonalnie myślący Meciszewski wytknął, że Senat już w trakcie obrad Sejmu zwracał się do Komisji, uznając de facto jej dalsze istnienie. Na zaprzeczenia senatorów wysuwał i inne argumenty - jeśli Senat (według własnej interpretacji) miał wnosić rachunki, które mu wcześniej NKO przedstawiła - to czemu tego nie zrobił? ${ }^{48}$

Sprawa ta stanęła na ostrzu noża podczas siódmej sesji, gdy Lipczyński zgłosił fakt ocenzurowania w drukowanym diariuszu jego wypowiedzi, zapowiadającej sprawozdanie $\mathrm{NKO}^{49}$. Było to o tyle istotne, że od roku 1833 obrady Zgromadzenia były tajne, a wprowadzenie i działania cenzury, która objęła nawet diariusze sejmowe, stanowiły również pole konfliktu z Senatem ${ }^{50}$. Ostatecznie drukowany diariusz sejmowy objął tylko siedem pierwszych posiedzeń i przestał się ukazywać.

\footnotetext{
${ }^{36}$ APK WM 19, k. 424-425.

${ }^{37}$ APK WM 19, k. 181-191, 424-425; Diariusz Sejmu 1837/38, s. 81.

${ }^{38}$ APK WMK IV 26, k. 194-195.

${ }^{39}$ APK WMK IV 26, k. 237-238.

${ }^{40}$ APK WMK II 42, k. 1107.

${ }^{41}$ APK WMK V 3, k. 559-560.

${ }^{42}$ Diariusz Sejmu 1837/38, s. 80.

${ }^{43}$ APK WMK II 41, k. 233.

${ }^{44}$ Na podstawie Statutu organicznego o zgromadzeniach politycznych, Dziennik Praw r. 1833.

${ }^{45}$ APK WMK II 41, k. 234.

${ }^{46}$ APK WMK II 41, k. 313

${ }^{47}$ Diariusz Sejmu 1837/38, s. 76; APK WMK II 42, k. 535-536.

${ }^{48}$ Diariusz Sejmu 1837/38, s. 74-75, 78.

${ }^{49}$ Ibidem, s. 74.

${ }^{50}$ J. Bieniarzówna, Z dziejów liberalnego i konspiracyjnego Krakowa (1833-1848), Kraków 1948, s. 41-42; T. Gutkowski, Cenzura w Wolnym Mieście Krakowie (1832-1846), Kraków 1914,
} passim. 
Sprawozdanie z działalności NKO (wówczas nazywane: „Zdanie sprawy z czynności”) było, ze względu na ustalenia Komisji, materiałem o wielkiej doniosłości. Działalność finansowa rządu poddana została druzgocącej krytyce. Pierwsza część sprawozdania relacjonowała działalność samej Komisji i jej długo bezskuteczne próby podjęcia obowiązków, natomiast druga to właściwy raport z badania rachunków, w którym przedstawiono „,nie bardzo pocieszający obraz stanu gospodarstwa skarbowego tutejszego kraju". Obszernie zostały w nim oświetlone problemy z ukonstytuowaniem się Komisji, problemy z niejasnością i brakiem uregulowań prawnych oraz negatywna rola, jaką odegrał w tych kwestiach Senat. Komisja przedstawiła nieporządek w rachunkach, które Senat przekazał. Padały ostre słowa o tym, że „w większej części” podane kwoty wydatków i dochodów nie zgadzają się załączonymi „dowodami”, a przedstawione liczby są ,improwizowane” przez rządowych rachmistrzów. W dalszej części analizie poddano całą rachunkowość rządową, poddając ją miażdżącej krytyce, wymieniając niezliczone błędy, uchybienia, mieszanie ze sobą różnego rodzaju funduszy i zwykły bałagan. Przez to ,wynalezienie prawdziwego stanu, czynnego lub biernego, funduszu ogólnokrajowego (...) zupełnie jest niepodobnym”. Badając legalność, według NKO właściwie nie można mówić o prowadzeniu gospodarki finansowej na podstawie budżetu, bo zarówno dochody jak i wydatki często opierały się na szczegółowych decyzjach Senatu podejmowanych pod wpływem chwili. Senat zresztą nie przejmował się podziałem władz, nakładając choćby - będąc przecież władzą wykonawczą - nowe obciążenia podatkowe ${ }^{51}$.

Po trwającym dwa dni (29 i 30 stycznia 1838 r.) odczytywaniu złożonego 27 grudnia 1837 r. dokumentu, wybuchła w Zgromadzeniu gorąca dyskusja. Wszczęta została po wniosku Meciszewskiego, który odczytawszy raport, wniósł o jego wydrukowanie. Spotkało się to z gwałtowną opozycją, przede wszystkim senatorów - byłych i obecnych (w skład Zgromadzenia wchodziło wówczas dwóch senatorów), w tym marszałka („Prezydującego w Zgromadzeniu"), którym był senator Wincenty Wolff. Atmosfera i padające oskarżenia skłoniły marszałka, który był jednocześnie członkiem senackiego Wydziału Skarbu, do zgłoszenia chęci ustąpienia ze stanowiska. Po uspokojeniu atmosfery ostatecznie Izba przegłosowała stosunkiem 16 do 8 wydrukowanie raportu Komisji ${ }^{52}$.

Jednak brak uregulowań prawnych powodował, że problemem było, co dalej zrobić z raportem. Postanowiono go odesłać do sejmowej Komisji Skarbu. Meciszewski chciał od razu przystapić do wyboru członków nowej Komisji Obrachunkowej, gdyż uważał, iż w tym miejscu poprzednia swą misję zakończyła. Jednak spotykając się ze sprzeciwem, w tym przewodniczącego Komisji

${ }^{51}$ APK WMK II 42, k. 1139-1205.

${ }^{52}$ APK WMK II 42, k. 416-439. 
Obrachunkowej Lipczyńskiego, ustąpił, a wybór nowej Nieustającej Komisji Obrachunkowej odłożono do momentu rozpatrzenia raportu przez sejmową Komisję Skarbową ${ }^{53}$.

Komisja Skarbowa złożyła swoją opinię już po dwóch dniach, na sesji odbywającej się 1 lutego. Być może sekret szybkości pracy tkwił w tym, że jej przewodniczącym był przewodniczący NKO Lipczyński. Przedstawił on wnioski Komisji Skarbowej, które Izba jednogłośnie przyjęła. Stwierdzono, że Senat nie wypełnił szeregu swoich obowiązków, nałożonych przepisami prawa. Na sesji tej wybrano nową Komisję Obrachunkową. Najwięcej głosów dostał Meciszewski, a ponadto członkami zostali Józef Louis i hrabia Kryspin Żeliński. Na zastępców wybrano Józefa Placera i Józefa Mączyńskiego. Dotychczasowi członkowie - Lipczyński i Rudowski otrzymali za mało głosów, by ponownie w niej zasiąść ${ }^{54}$.

Zgromadzenie Reprezentantów podziękowało członkom dotychczasowej Komisji, dając świadectwo „z przykładnej ich gorliwości zadowolenia”, polecając wdzięczności obywateli dzieło Lipczyńskiego, Meciszewskiego i Rudowskiego, dzięki któremu możliwe było poznanie sposobu wydatkowania pieniędzy publicznych ${ }^{55}$.

VI. Zgromadzenie Reprezentantów zdążyło jeszcze przekazać nowo wybranej Komisji przesłane przez Senat rachunki Komisji Emerytalnej sięgające 1 czerwca 1837 r., aby NKO o ich rewizji mogła poinformować kolejny Sejm. Przy okazji pouczono Senat, iż w przyszłości takie rachunki winien przesyłać właśnie bezpośrednio do Komisji Obrachunkowej ${ }^{56}$.

Do rozwiązania problemu formy działania NKO konieczne było zwrócenie się do Konferencji Rezydentów, którzy zgodzili się 4 lutego przyjąć wybraną 30 stycznia przez Zgromadzenie deputację z memoriałem w sprawie Komisji Obrachunkowej. Deputacja została przyjęta w siedzibie misji pruskiej, gdzie potwierdzono jej fakt otrzymania obu (senackiego i pochodzącego od samej NKO) projektów statutu dla Komisji Obrachunkowej. Zapewniono, iż zostaną one rozważone i że powstanie Statut Organiczny dla tej instytucji, „ogłoszony urzędownie" 57 .

Na temat nowo wybranej Komisji narosło sporo nieścisłości ${ }^{58}$. Nowa NKO zajęła się działaniami, które - choć niewątpliwie służyły wzmocnieniu jej pozycji - stanowiły też niewątpliwie wyzwanie rzucone wobec władz i ist-

${ }^{53}$ APK WMK II 42, k. 449-451.

${ }^{54}$ APK WMK II 42, k. 1431; WMK II 41, k. 483-484.

${ }^{55}$ APK WMK II 42, k. 1593.

${ }^{56}$ APK WMK II 42, k. 1455-1456.

${ }^{57}$ APK WMK II 41, k. 549.

${ }^{58}$ Zob. J. Bieniarzówna, op. cit., s. 46; eadem, Wolne Miasto Kraków, [w:] eadem, J. Małecki, Dzieje Krakowa, t. 3, Kraków 1986, s. 90-92. 
niejących uregulowań. Wbrew przepisom, Komisja uznała, że pracować będzie w składzie pięcioosobowym, a komplet stanowią trzy osoby. Do tego tym razem wbrew wynikom głosowania w Izbie - Komisja wybrała na swego przewodniczącego hrabiego Kryspina Żelińskiego. Dodatkowo jeszcze, chcąc rozbudować swój personel, zwróciła się do Senatu z potrzebą zatrudnienia zastępcy sekretarza ${ }^{59}$.

Sytuacja sprawiła, że Senat mógł pozwolić sobie na położenie kresu istnienia Komisji. Sprawa oparła się o Konferencję Rezydentów, która 10 kwietnia 1838 r. zezwoliła Senatowi na zawieszenie funkcjonowania Komisji Obrachunkowej ${ }^{60}$. Konferencja Rezydentów, odrzucając oba projekty Statutu dla Komisji Obrachunkowej (jeden pochodzący od niej samej, drugi senacki), zdecydowała o zawieszeniu działalności Komisji właśnie do czasu zaprojektowania i wydania dla niej statutu.

Senat reskryptem wezwał Komisję Obrachunkową do zawieszenia działania i wydania posiadanych akt, lecz ta odmówiła, stojąc na gruncie prawa i kwestionując upoważnienie pochodzące od Rezydentów. W literaturze przeczytać można ${ }^{61}$, że Senat zażądał zwrotu dokumentów od NKO. Jednak właściwie jedyne istotne papiery, jakie ta mogła posiadać, to te przekazane przez Zgromadzenie Reprezentantów, a dotyczące Komitetu Emerytalnego. Sama konieczność ich zwrotu wynikała ze zmian w ustawie emerytalnej, które przeprowadził sejm.

Jak relacjonował Meciszewski, 23 maja przy licznie zgromadzonej publiczności, „policją i siłą zbrojną” siedziba Komisji została opanowana, a ona sama rozpędzona ${ }^{62}$. Być może to tylko wizja literacka, bo treści takie opublikowano we Francji, jako głos w obronie Rzeczpospolitej Krakowskiej. W oficjalnych źródłach bowiem odbierający akta archiwista Senatu Ignacy Kaczkowski wspomniał tylko o pomocy ślusarza, gdyż Meciszewski odmówił wydania kluczy. Pomieszczenie i akta zostały zapieczętowane ${ }^{63}$.

Jeszcze 29 maja hrabia Żeliński pozwolił sobie na wysłanie listu do Senatu, tytułując się prezesem Komisji Obrachunkowej. Senat zadziałał zdecydowanie, zwracając się do Rezydenta Austriackiego, gdyż Żeliński był poddanym austriackim. Rząd poinformował nie tylko o uzurpacji, ale również o wcześniejszej odmowie uzyskania przez niego zgody na pełnienie urzędu w Wolnym Mieście, co winien dopełnić. Groźba nie tylko zakazu pełnienia jakichkolwiek urzędów w Rzeczpospolitej Krakowskiej, ale nawet w niej przebywania, sprawiła, że Żeliński całkowicie zmienił podejście i wysłał do Senatu przepro-

\footnotetext{
${ }^{59}$ APK WMK IV 27, k. 69-70.

${ }^{60}$ L. Królikowski [H. Meciszewski], Memoriat historyczny i polityczny o stanie obecnym Wolnego Miasta Krakowa i Jego Okręgu, Paryż 1840, s. CX-CXI.

${ }^{61}$ J. Bieniarzówna, op. cit., s. 46.

${ }^{62}$ L. Królikowski [H. Meciszewski], op. cit., s. 176.

${ }^{63}$ APK WMK IV 27, k. 107.
} 
siny, w których prosił o zwrot listu i traktowanie przysłanej korespondencji jako niebyłej ${ }^{64}$.

VII. Dotychczas uważano, że w 1838 r. krótkie, burzliwe losy Nieustającej Komisji Obrachunkowej Rzeczypospolitej Krakowskiej dobiegły końca. Tak się nie stało. Prace nad powołaniem w nowej formie kontroli państwowej płynęły jednak niespiesznie. Dopiero 26 października 1838 r. Senat przyjął projekt Statutu postępowania dla Komisji Obrachunkowej, przygotowany wskutek wezwania Rezydentów. W 1840 r. Rezydenci informowali o potrzebie przyjęcia przepisów przejściowych, które zapewniłyby ciagłość pracy i ułatwiły wykonanie zadań przyszłej Komisji. Te przygotował wkrótce Senat ${ }^{65}$. Wreszcie w 1842 r. Komisja Obrachunkowa pojawia się na nowo. Do nowego Statutu Organicznego urządzającego Zgromadzenia Polityczne, wydanego przez Konferencję Rezydentów, wprowadzono przepisy odnoszące się do Komisji Obrachunkowej, a dla niej samej wydano dołączony, osobny Statut Organiczny, który tylko za zgodą Rezydentów mógł być zmieniony.

Statut Organiczny dla Komisji Obrachunkowej był pierwszą (i jedyna) osobną regulacją kontroli państwowej w Rzeczpospolitej Krakowskiej. Definiował on, iż NKO jest ustanawiana przez Sejm, a za zadanie ma wykonywanie ,porządkowania i kontrolowania rachunkowości wszystkich gałęzi administracji (...) pomiędzy jednym a drugim sejmem”. Jednak charakter organu uległ zmianie. Statut dla Zgromadzeń określał skład Komisji na pięć osób wybranych przez Sejm ze swego grona i szóstej - delegowanej przez rząd spośród swoich członków. Ów senator z mocy prawa był przewodniczącym Komisji, wraz z nim dopiero Komisja stanowiła komplet mogący pracować, i za jego pośrednictwem utrzymywała kontakt z Senatem - zresztą jedynym organem, do którego mogła się zwracać bezpośrednio. Przewodniczący posiadał szerokie kompetencje, łącznie z prawem zwoływania czy zawieszania zebrań.

Sejm wybierał oprócz pięciu członków jeszcze pięciu zastępców, którzy $\mathrm{w}$ razie śmierci, choroby czy innych przeszkód uniemożliwiających pracę, mieli - na wezwanie Senatu - zastępować członków Komisji. Członkowie komisji pozbawieni byli immunitetu, jaki posiadali członkowie Zgromadzenia Reprezentantów, a gdyby któryś z nich był wybrany na nowy Sejm, to nie mógł zasiadać w komitecie skarbowym, który miał za zadanie m.in. badanie rachunków przedstawionych przez Senat.

Komisja zbierać się miała jedynie raz do roku, celem rewizji rachunków dochodów i wydatków krajowych z roku minionego, które Senat miał przed-

${ }^{64}$ APK WMK IV 27, k. 111, 119-120.

${ }^{65}$ APK WMK IV 36, k. 3, 43. 
stawiać 1 lipca. Komisja miała czas trzech miesięcy, bez możliwości przedłużenia, i do 1 października winna zwrócić rachunki oraz przesłać Senatowi swe o nich uwagi. Rozważyć je miał specjalny komitet senacki.

Przewidziano szczegółową procedurę przeprowadzania kontroli. Złożone rachunki miały być uprzednio sprawdzone przez Biuro Rachunkowe Senatu i przez nie zatwierdzone. Rachunki powinny odpowiadać zapisom budżetowym i miały obejmować jedynie rok, a zaległości z lat ubiegłych miały być księgowane oddzielnie. Natomiast sama kontrola miała rozpoczynać się od sprawdzenia, czy rachunki ogólne zgadzają się z załącznikami i sprawdzenia zgodności rachunków z przepisami dotyczącymi rachunkowości. W przypadku przychodów istotne było, czy miały podstawę w budżecie. Co do wydatków, NKO miała porównać zapisy budżetowe z poniesionymi wydatkami. Swoje uwagi spisywać miała w przewidzianej formie szczegółowo zaprojektowanego protokołu. Poszczególne jego rubryki miały przedstawiać kolejno numer, przedmiot dochodu lub wydatku, kwotę rzeczywistą i zapisaną w budżecie oraz wyliczoną między nimi różnicę, opinię Komisji Obrachunkowej i odpowiedź Senatu. Kolejną rubrykę z uwagami wypełniać miał sejmowy Komitet Skarbowy, a w ostatnią sekretarz sejmowy wpisywać miał decyzję izby ${ }^{66}$.

Ustawa przejściowa rozwiązywała ostatecznie wybraną przez sejm, a później zawieszoną w 1838 r. Komisję Obrachunkową, powołując na jej miejsce nową, zorganizowaną według przepisów nowego statutu. $Z$ tej przyczyny też Komisja składać się miała (wyjątkowo, po raz pierwszy) z osób mianowanych przez Konferencję Rezydentów spośród Reprezentantów (zasiadających w 1837/38 roku) lub nawet innych osób ${ }^{67}$.

Ograniczona, pozbawiona praw i zależna od rządu Komisja Obrachunkowa tworzyła karykaturę kontroli państwowej. O jej istnieniu przypomniał sobie senacki Wydział Dochodów Publicznych, na którego wniosek Senat Rządzący zwrócił się 18 sierpnia 1843 r. do Konferencji Rezydentów Trzech Opiekuńczych Dworów o mianowanie członków Komisji Obrachunkowej według przepisów przejściowych. Konferencja Rezydentów powołała członków owej komisji, którymi zostali uczestnicy poprzedniego Zgromadzenia: Józef Louis, Michał Okoński, Józef Placer, ksiądz Mateusz Gładyszewicz i Antoni Matakiewicz. Zastępcami mianowano Antoniego Zygmunta Helcla i Karola Treytlera $^{68}$. Senat ze swej strony delegował Ludwika Sobolewskiego, który objąć miał przewodnictwo Komisji.

Prace tak powołanej Komisji Obrachunkowej nie przyniosły efektów, co zresztą wytykała Komisja Skarbowa Zgromadzenia Reprezentantów ${ }^{69}$.

\footnotetext{
${ }^{66}$ Dziennik Praw, r. 1842.

${ }^{67}$ Ibidem.

${ }^{68}$ APK WMK IV 36, k. 86, 88-89.

${ }^{69}$ APK WMK II 43, k. 549-555.
} 
Nie udało się jej sprawdzić rachunków państwowych, bo - jak tłumaczył na sesji sejmowej Michał Okoński - w czasie dwóch miesięcy niemożliwe było skontrolowanie dokumentacji finansowej ostatnich dziesięciu lat, którą musiały przewozić aż „trzy bryki”. Dlatego Komisja nie przedstawiła swojego raportu, jednak Okoński twierdził, że Senat udzielał jej wszelkich wyjaśnień. Wywiązała się dyskusja, w toku której głos zawierał m.in. Meciszewski ${ }^{70}$.

Izba Reprezentantów w 1844 r. wybrała nową Komisję Obrachunkową. W jej skład weszli: Konstanty Benöe, Julian Florkiewicz, Jan Librowski, Franciszek Stachowski i Marcin Soczyński. Natomiast na zastępców członków wybrani zostali: Franciszek Hahn, Stanisław Ciechanowski, Stanisław Zamoyski, Kajetan Kowalski i Kazimierz Jadowski ${ }^{71}$. Do Komisji nie wszedł Hilary Meciszewski, który wyraźnie prosił o niewybieralnie go, tłumacząc się swoim dwukrotnym w niej udziałem i koniecznością zaznajamiania się z tajnikami finansów kolejnych osób. Jednak współcześni zarzucali mu, iż został przekupiony przez władzę, i ze względu na polepszenie działania administracji, zaprzestał działalności opozycyjnej ${ }^{72}$. W tym duchu zresztą wypowiadał się, zauważając, że dopiero po 1838 r. Senat uporządkował rachunkowość i przestał torpedować jej weryfikację ${ }^{73}$.

Senat na wniosek Wydziału Dochodów Publicznych powołał senatora Jacka Księżarskiego do przewodniczenia Komisji i rozkazał podjęcie przez nią pracy począwszy od 1 listopada $1844 \mathrm{r}^{74}$ Brak jednak zachowanych śladów jej działalności. Komisja zresztą nie mogła już wypełnić swego zadania, gdyż nigdy już nie zebrał się sejm Rzeczypospolitej Krakowskiej. Niecałe dwa lata później wybuchło powstanie krakowskie, którego upadek pociagnął za sobą zakończenie istnienia Wolnego Miasta Krakowa.

Krótko po pacyfikacji, gen. Castiglione, który z ramienia Austrii pełnił w zajętym Krakowie funkcję Naczelnika Tymczasowego Administracji Cywilno-Wojskowej, zarządził przegląd istniejących w Krakowie urzędów, celem przeprowadzenia oszczędności na niepotrzebnych w zmienionej sytuacji instytucjach. Wydział Dochodów Publicznych przy Radzie Administracyjnej (która zastąpiła Senat) zgłosił m.in. jako niepotrzebną Komisję Obrachunkowa. Dnia 18 maja 1846 r. gen. Castiglione zadecydował o jej likwidacji ${ }^{75}$.

\footnotetext{
${ }^{70}$ APK WMK II 43, k. 557-559.

${ }^{71}$ APK WMK II 43, k. 561-564.

${ }^{72}$ W. Kopff, Wspomnienia z ostatnich lat Rzeczypospolitej Krakowskiej, Kraków 1906, s. 52, 57; J. Bieniarzówna, Rzeczpospolita Krakowska 1815-1846, Kraków 1948, s. 76.

${ }^{73}$ APK WMK II 43, k. 538, 544.

${ }^{74}$ APK WMK IV 33, k. 210.

${ }^{75}$ APK WMK IV 37, k. 51-52.
} 
VIII. Nieustająca Komisja Obrachunkowa nie była zwykłym organem kontroli państwowej. W specyficznych warunkach Rzeczypospolitej Krakowskiej odegrała też istotną rolę polityczną, i - jak pisała znawczyni dziejów Krakowa - „okazała się najbardziej opozycyjną instytucją w dziejach Wolnego Miasta" ". Pomimo specyfiki Wolnego Miasta Krakowa, istnienie i działalność tego organu stanowi element dziejów kontroli państwowej w Polsce.

${ }^{76}$ J. Bieniarzówna, op. cit., s. 34. 